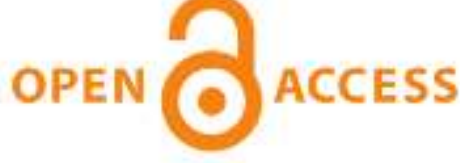 \\ International Journal of Applied Sciences and Biotechnology
}

A Rapid Publishing Journal

\section{ISSN 2091-2609}

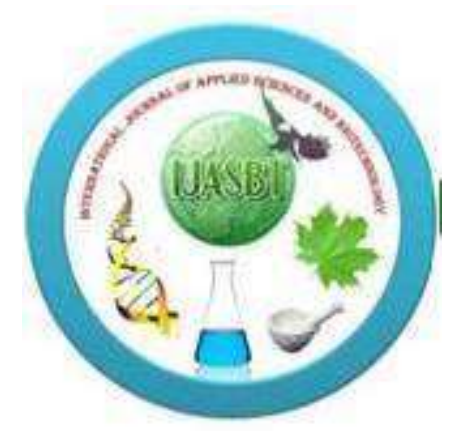

\section{Available online at:}

\author{
$\frac{\text { http://www.ijasbt.org }}{\&}$
}

http://www.nepjol.info/index.php/IJASBT/index

\section{Indexing and Abstracting}

CrossRef, Google Scholar, Global Impact Factor, Genamics, Index Copernicus, Directory of Open Access Journals, International Society of Universal Research in Sciences (EyeSource), Journal Seeker, Socolar, BioRes, Indian Science, Jadoun Science, Jour Informatics, Journal Directory, JournalTOCs, Academic Journals Database, Journal Quality Evaluation Report, PDOAJ, Science Central, Journal Impact Factor, NewJour, Open Science Directory, DRJI, Global Institute of Scientific Information, Open Access Library, IIJS, Sciseek, Cabell's Directories, Scientific Indexing services, CiteFactor, Unisa, InfobaseIndex, Infomine, Getinfo, Open Academic Journals Index etc.

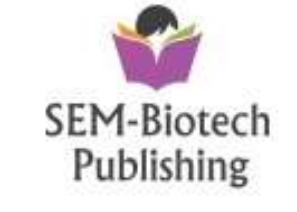

IC Value: 4.37 


\title{
AN INVESTIGATION ON PRINCIPLE BIOCHEMICAL COMPONENTS, PHOTOSYNTHETIC PIGMENTS, NUCLEIC ACID AND ENZYMATIC ACTIVITIES OF AXENIC CULTURE OF SCYTONEMA SP. TREATED WITH TWO PAHS: ACENAPTHENE AND FLUORANTHENE
}

\author{
Miral Patel ${ }^{* 1}$, Nirmal Kumar J.I. ${ }^{2}$ and K.K.Tiwari ${ }^{1}$ \\ ${ }^{1}$ Sophisticated Instrumentation Center for Applied Research and Testing (SICART), Vallabh Vidya Nagar, Gujarat India- 388120. \\ ${ }^{2}$ P.G. Department of environmental Science and Technology, Institute of Science and Technology for Advanced Studies and Research (ISTAR), Vallabh \\ Vidya Nagar, Gujarat India- 388120. \\ *corresponding author e-mail: miral24@gmail.com
}

\begin{abstract}
The fresh water cyanobacteria Scytonema sp. was cultivated in a laboratory scale in the presence of various concentrations $(2.5,5,10,20 \mathrm{ppm})$ of two polycyclic hydrocarbons in order to assess the influence of the pollutant on the growth and certain physiological responses of the cyanobacteria. The algal cells were analyzed for chlorophyll $a$, carotenoids, phycobilliproteins, proteins, amino acid, nucliec acid, $\mathrm{C} / \mathrm{N}$ ratio and elemental composition, carbohydrate and different enzymes at four days interval up to 16 days. According to our results, Scytonema sp. was significantly affected by the pollution with regard to the different physiological parameters examined, and this significance may be negative, positive or variable. The effect of the pollutant on carbohydrate, and the total amount of amino acids, proteins was negative, however, the composition of the phenol increase with raise in PAHs concentration. A positive effect of the pollutant on cellular $\mathrm{C} / \mathrm{N}$ ratio was observed up to certain doses of PAHs.
\end{abstract}

Key Words: PAHs; Scytonema sp.; biochemical; enzyme activities; pigments; DNA; RNA; C/N ratio.

\section{Introduction}

The quality of water is currently a vital question in several regions around the world. Among the several contaminants that are recognized as threats to aquatic systems, high environmental concern has been devoted to polycyclic aromatic hydrocarbons (PAHs) (OSPAR-Commission, 2000). These compounds are among the most important and ubiquitous anthropogenic chemicals detected in the environment (Botta et al., 2009) and have been considered as highly hazardous by the United States Environmental Protection Agency (Office of the Federal Registration, 1982) and the European Union (Vives et al., 2004), mainly due to their toxicity (Mastral and Callén, 2000). PAHs have been recognized as mutagenic, carcinogenic and teratogenic (Oliveira et al., 2007) and exposure to these compounds has been linked to effects at higher levels of biological organization (Jensen et al., 2008). In this perspective, there is an increasing concern about the deleterious effects of these compounds in estuarine and coastal ecosystems considering that, unlike other harmful organic chemicals that have been banned or regulated in discharges, they continue to be released into the environment due to several natural phenomena and anthropogenic activities such as burning of fossil fuels and spills, oil and gas extraction, transformation, transport and use (Arias et al., 2009) and have a wide range of physical, chemical, and biological effects in biotic and abiotic communities (Albers, 1995). Different technologies have been used either to partially degrade these contaminants and remove them from the environment or to mineralize them to non-toxic compounds. Recent reports have demonstrated that photosynthetic microorganisms, particularly cyanobacteria, may play a direct or indirect role in the metabolism and degradation of hydrocarbons (Yehuda Cohen 2002). The availability of powerful genetic techniques allow the biotechnological application of cyanobacteria to produce specific products, to biodegrade organic pollutants in surface waters, to control mosquitoes and for many different other purposes (Koksharova and Wolk 2002). 
Until now, there is no detailed report concerning toxicity of Fluoranthene and Acenapthene on Scytonema sp. The aim of this study is to provide toxicological information about Fluoranthene and Acenapthene on cyanobacterial species: Scytonema sp. In most of studies with cyanobacteria, it was not clear whether the strains used were definitively axenic (Abed and Ko"ster 2005). It is known to be very difficult to cultivate cyanobacteria in axenic culture and to clean them from naturally associated aerobic heterotrophic bacteria. In this study, I have selected axenic unicyanobacterium strain of Scytonema sp. to observe effect on its physiological and metabollic changes by two PAHs.

\section{Materials and Method}

For measurement of pigments, metabolites, $\mathrm{C} / \mathrm{N}$ ratio and enzyme activities, cultures were grown in nitrogen-deficient BG11 medium for heterocystous, nitrogen fixing forms. All the experiments were carried out in triplicates. Samples were thoroughly homogenized and drawn during exponential phase of growth for further analysis. Fluoranthene were purchased from Sigma-Aldrich and Acenapthene was Himedia made. LC50 values of the Scytonema sp. for Fluoranthene and Acenapthene were determined in terms of quantitative estimation of chlorophyll-a and accordingly, various concentrations of the PAHS were used in all further experiments (Table 1). Sterile cultures and conditions are maintained throughout the experimental period. Stock solution of both the PAHS were prepared in HPLC grade Milli-Q water and added aseptically to the culture medium to the final concentrations indicated for each treatment.

\section{Axenic Culture Preparation}

Cyanobacterial culture were procured from the Centre for Conservation and Utilization of Blue Green Algae, IARI, New Delhi, India.These cultures were subjected to different trials to employ bacteria-free cultures and investigate the growth of bacteria every $20 \mathrm{~d}$ throughout the experimental period, according to Felfoldy and Zsuzsa (1959) and Hoshaw and Rosewski (1973).

\section{Pigments measurement}

Chl-a was measured spectrophotometrically in cell lysates after extraction in $80 \%$ acetone (Jeffrey and Humphrey 1975). Phycobilliproteins was measured as described by Bennett and Bogorad (1973). All spectrometer reading were taken in UV-VIS-NIR spectrophotometer, Lamda-19, Perkin Elmer made.

\section{Metabolite estimation}

Carbohydrates were assayed quantitatively as per Roe (1955), total soluble proteins were determined as described by Lowry et al. (1951), amino acids were estimated by the method of Lee and Takahasi (1966), whereas phenols were measured according to Malick and Singh (1980).

\section{Enzyme assays}

The estimation of in vivo nitrate reductase activity was measured by the method of Sempruch et al. (2008), glutamine synthetase activity was done by $\gamma$-glutamyl transferase as described by Pamiljans et al. (1962) and succinate dehydrogenase activity, a major respiratory enzyme present in the thylakoid of the cyanobacteria was measured by the method of Kun and Abood (1949).

\section{Estimation of Carbon and Nitrogen}

These were determined using the elemental analyzer PE2400 Series II CHNS/O. The C/N ratio was determined as the mean of three samples with $\mathrm{SD} \pm 0.1$.

\section{Nucleic acid estimation}

The culture was centrifuged, and the supernatant was discarded, to the pellet $4 \mathrm{ml}$ of tris-EDTA buffer ( $\mathrm{pH} 8.0$ ), $2 \mathrm{ml}$ of $1 \%$ sodium dodecyl sulfate and $1 \mathrm{ml}$ sodium saline citrate (pH 7.0) was added and crushed using mortar and pestle. Equal volumes of chloroform/isoamyl alcohol (24:1, $\mathrm{v} / \mathrm{v}$ ) were added. The mixture was shaken for $20 \mathrm{~min}$ on a rocker and centrifuged at $3000 \mathrm{rpm}$ for $10 \mathrm{~min}$. The clear upper aqueous phase containing nucleic acids was used for estimation of DNA and RNA. The amount of DNA was determined quantitatively using diphenylamine reagent by standard procedure. The absorbance was measured at 595 nm. RNA content was estimated 12 by using orcinol solution and measured at $670 \mathrm{~nm}$. Amounts of DNA and RNA were calculated from standard graph and expressed as $\mathrm{mg} \mathrm{ml}^{-20}$ (Plummer DT. 1998).

Table 1: LC50 values and PAHS treatments of the test organisms for Fluoranthene and Acenapthene.

\begin{tabular}{|l|l|l|l|}
\hline $\begin{array}{l}\text { Organism selected for } \\
\text { study }\end{array}$ & Xenobiotic compounds & $\begin{array}{l}\text { LC50 values Determined } \\
(\mathbf{p p m})\end{array}$ & $\begin{array}{l}\text { Treatments decided based } \\
\text { upon LC50 (ppm) }\end{array}$ \\
\hline \multirow{3}{*}{ Scytonema sp. } & \multirow{3}{*}{$\begin{array}{l}2.5 \\
5\end{array}$} & $\begin{array}{l}5 \\
10\end{array}$ \\
\cline { 2 - 4 } & Acenapthene & 5 & 5 \\
& & 10 & 20 \\
\hline
\end{tabular}




\section{Result and Discussion}

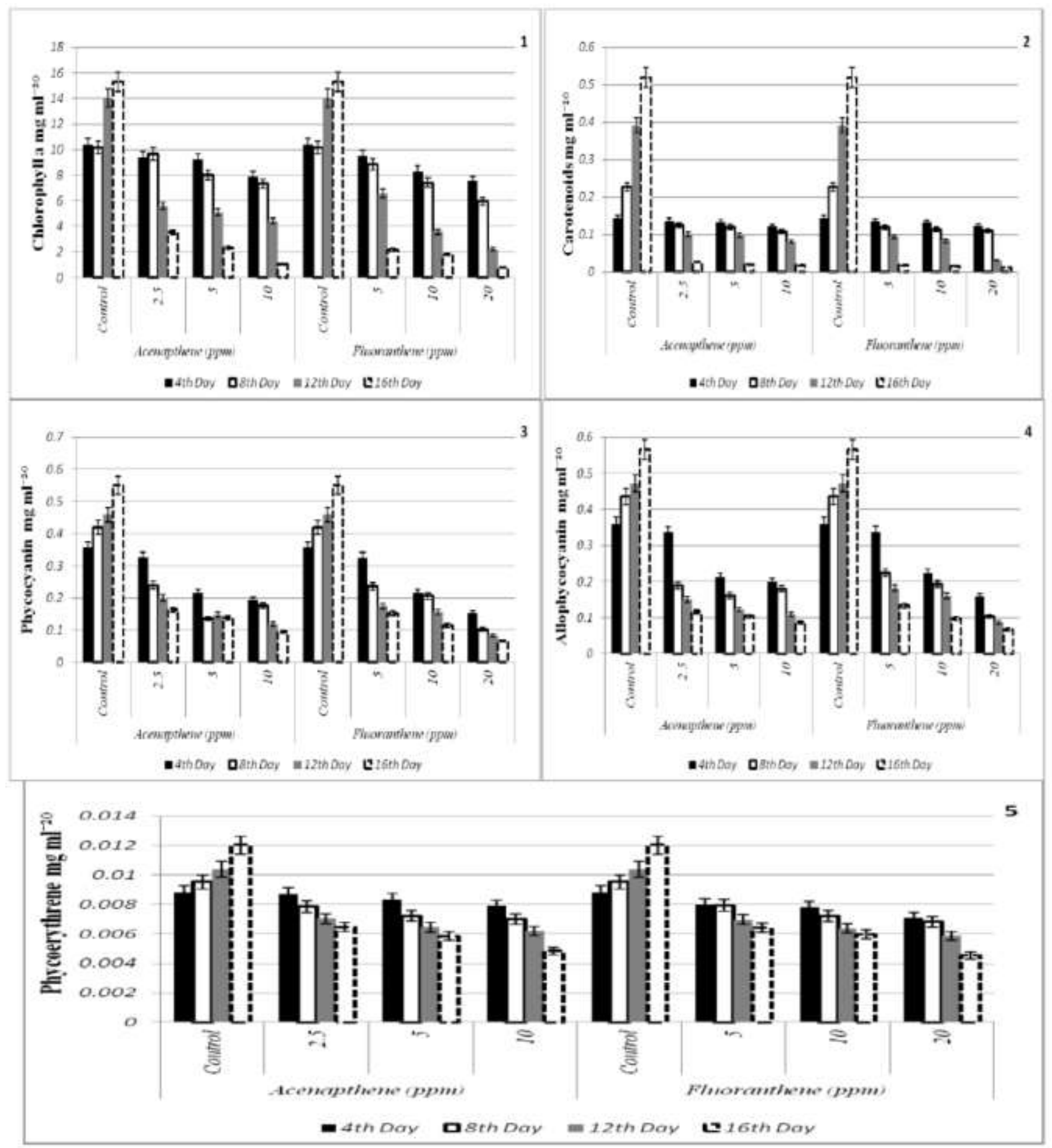

Fig. 1, 2, 3, 4 and 5: Impact of two PAHs on Scytonema sp. in respect to time.

The growth of Scytonema was measured in terms of the level of the Chl-a. The results clearly revealed that the levels of pigments of the Scytonema decreased with rising PAHS concentrations in the culture medium. The decline in the pigments with respect to increasing exposure periods (days) was more prominent and highly significant at higher doses as compared with lower doses. The pigments Chl-a, carotenoids, and phycobilliproteins (phycocyanin, allophycocyanin, and phycoerythrene) of the organism decreased continuously with increasing PAHS concentrations. The percentage reductions at the highest Acenapthene concentration $(10 \mathrm{ppm})$ were $93 \%, 97 \%$, $82 \%, 84 \%$, and $59 \%$ for Chl-a, carotenoids, phycocyanin, allophycocyanin, and phycoerythrene, respectively, by the end of 16 days. Same as with Fluoranthene treated Scytonema, decrease by $0.810 \pm 0.055 \mathrm{mg} \mathrm{ml}^{-20}$, $0.011 \pm 0.003 \mathrm{mg} \mathrm{ml}^{-20}, 0.066 \pm 0.004 \mathrm{mg} \mathrm{ml}^{-20}, 0.067 \pm 0.008$ $\mathrm{mg} \mathrm{ml}^{-20}$ and $0.0045 \pm 0.0005 \mathrm{mg} \mathrm{ml}^{-20}$ at the end of 16 days (20ppm) was observed (Fig 1, 2, 3, 4 and 5). The growth of Scytonema sp. was negatively affected by the PAHs since 
the cell number gradually fell with increasing concentrations of the PAHs to less than a quarter of the initial number in highest concentration of treated cells relative to the control. Growth reduction by oil pollution, including diesel fuel, has been demonstrated in many algal species, e.g. Scenedesmus quadricauda (Dennington et al. 1975), Isochrysis sp. (Ansari et al. 1997). The reduction in algal cell number may be accompanied by delayed cell division: this delay is proportional to the concentration of xenobiotic compounds added, which in turn is a function of the decrease in algal cell bioavailability under these conditions of stress (Nagwa Gamal et. al, 2005), also further stated that Diesel fuel is a hydrophobic compound and, when applied to $N$. salina, disrupts the optimal physical state of cytoplasmic membranes, thus disturbing the osmotic balance of the algal cell. Accordingly, cell permeability increases, which in turn stimulate the influx of the pollutant and probably the accumulation of a high quantity of hydrocarbons, which causes cell swelling. As a result, the pollutant has a positive significant effect on cellular chlorophyll $a$ production. Carbohydrates are the first products of photosynthesis in all algae (Calvin-Benson
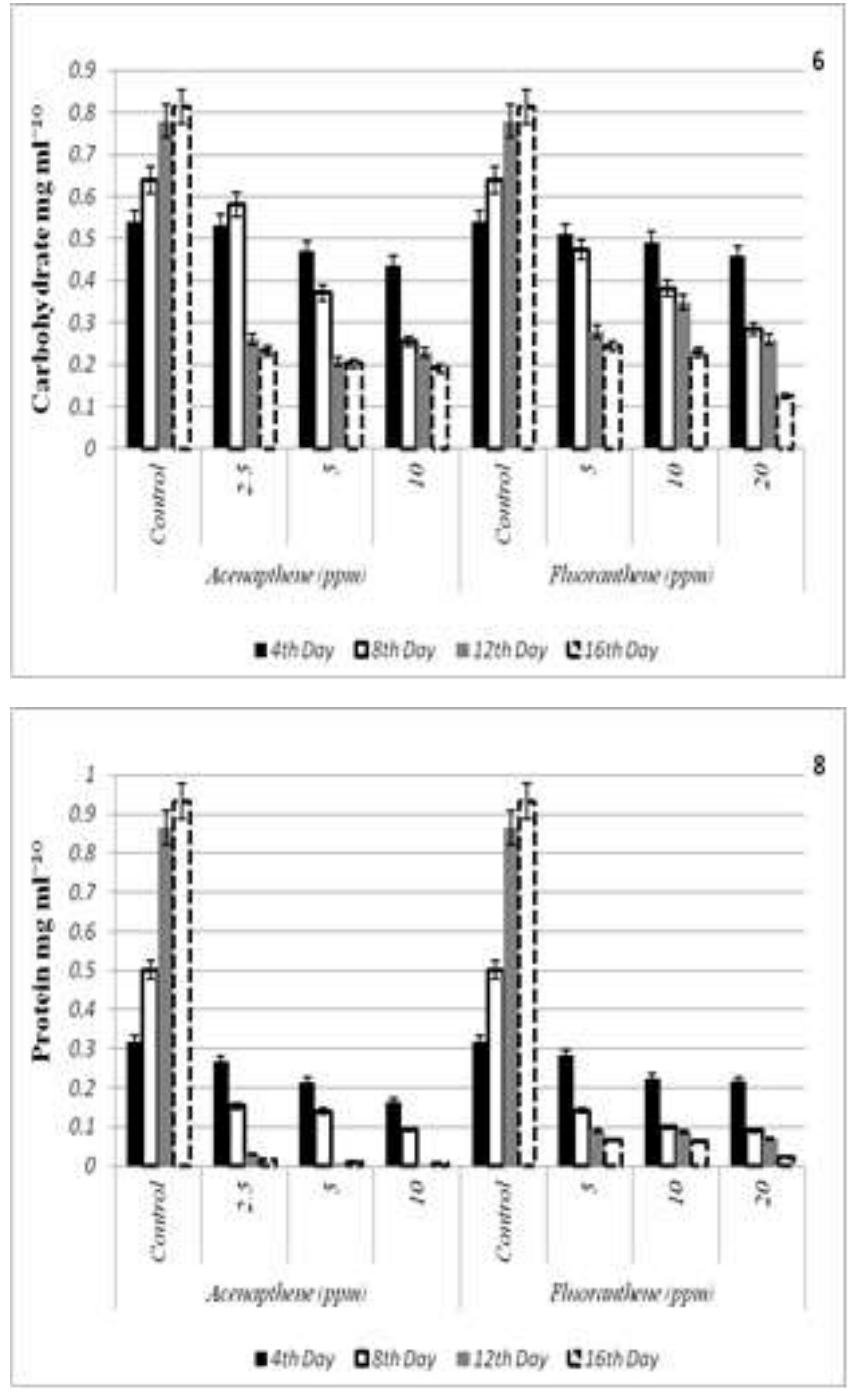

cycle) and provide the precursors for all cell components. (Fig 6, 7, 8 and 9) Cellular carbohydrates vary quantitatively according to culture conditions (Brown et al. 1998). A remarkable decrease of carbohydrate inhibition was observed with increasing concentrations of acenapthene by $76 \%$ reduction and for fluoranthene by $84 \%$ of total carbohydrates reduction by the end of 16 days. This observation is in agreement with other reported findings Rajendran et al. 2007. Moreover, some reports Kanika et al. (2003) also emphasize the concentration and timedependent retardation of carbohydrate levels in cyanobacterium. Further application of two PAHs to Scytonema sp. suppressed the total protein content in comparison with the control, the effect being more pronounced at higher doses. A considerable reduction of $0.0063 \pm 0.030 \mathrm{mg} \mathrm{m}{ }^{-20}$ (acenapthene $10 \mathrm{ppm}$ ) and $0.0238 \pm 0.006 \mathrm{mg} \mathrm{ml}^{-20}$ (fluoranthene $20 \mathrm{ppm}$ ) in the total protein content was registered at the end of 16 days respectively. Kapoor et al. (1996) reasoned that the interruption of protein synthesis could be due to the inhibition of enzymes and structural proteins essential for growth of the organism. A gradual reduction of up to
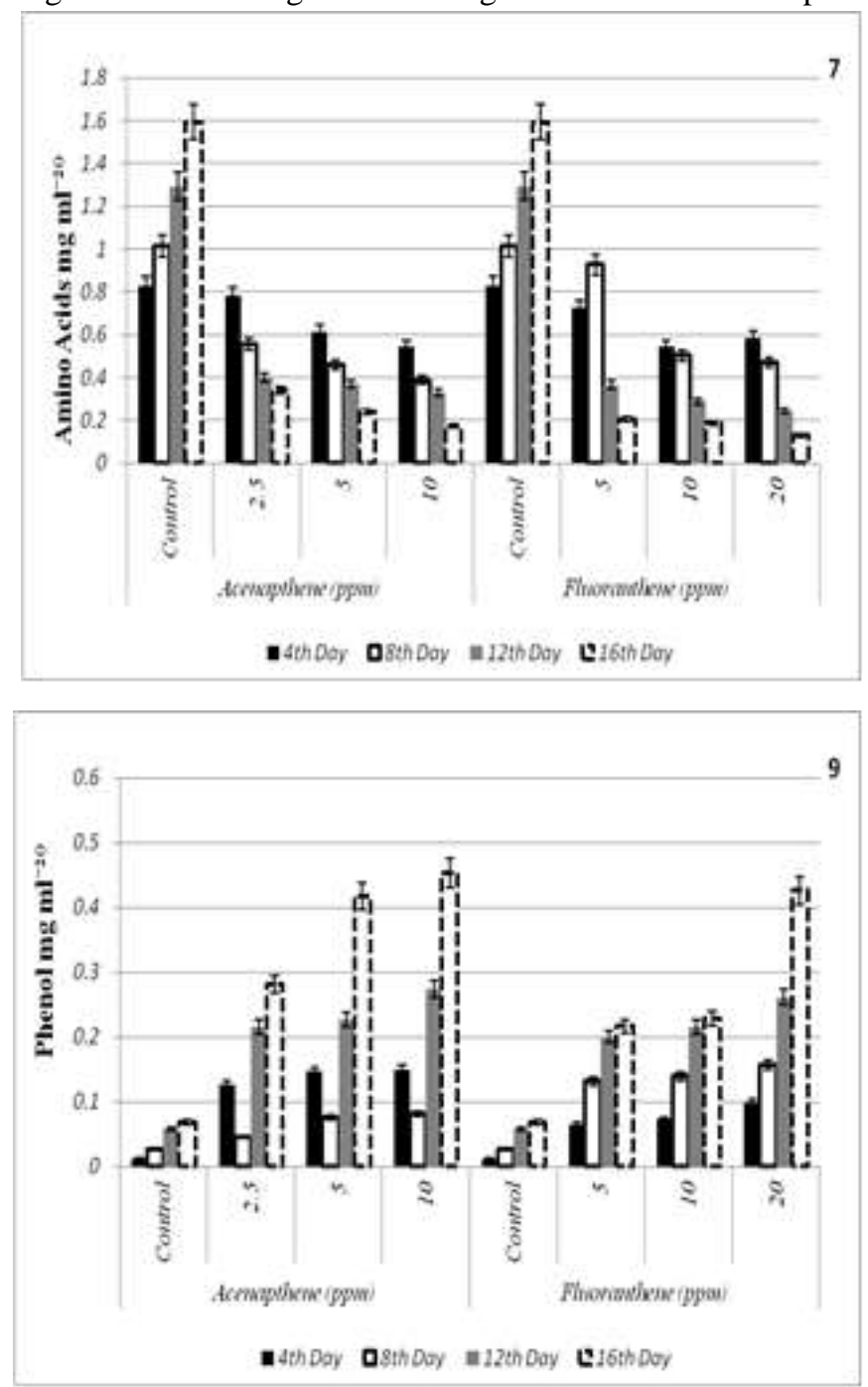

Fig. 6, 7, 8, and 9: Impact of two PAHs on Scytonema sp. in respect to time 
$0.172 \pm 0.009 \mathrm{mg} \mathrm{ml}^{-20}$ in acenapthene and $0.128 \pm 0.008 \mathrm{mg}$ $\mathrm{ml}^{-20}$ in fluoranthene to the total amino acids content at the end of 16 days was recorded when the cells were treated with $10 \mathrm{ppm}$ and $20 \mathrm{ppm}$ of two PAHs. When reflecting upon a decline in protein and amino acids content as a result of PAHS use, Piehler et al. (2003) considered that the reduction of algal metabolites resulting from diesel spills might be due to inhibition of cell division. Previous studies have shown that cellular amino acids are affected by external environment stress (Barrett \& Elmore 1998, ElSheekh 2000). The reduction effect of pollution by aqueous diesel fuel on the amounts of different amino acids may be an indirect reflection of the reduction in carbohydrate content. Another report suggests that the changes in amino acid concentrations may be due to the synthesis from endogenous precursors or by the inhibition of normal catabolism. Phenols are important aromatic molecules formed during stress conditions, which in turn trigger various biochemical processes within organisms. Phenol content in response to increasing concentrations of the PAHs has been represented. An increase in the phenol content was registered throughout the treatment. This could be due to the possible conversion of primary metabolites into phenols as well as to the accumulation of PAHs during stress conditions, which could corroborate other findings Mallick et al. 1994.

PAHs treatments of nitrate reductase, glutamine synthetase, and succinate dehydrogenase were used to suppress the activities of nitrogen-fixing, ammonia-assimilating, and respiratory enzymes, respectively, for Scytonema. Moreover, the highest doses of PAHs were more suppressive to the activities of the three enzymes. Nitrate assimilation is the major process of nitrogen acquisition in cyanobacteria Guerrero et al. 1981. It is transported into the cells by an active transport system and reduced to ammonium by the sequential action of nitrate reductase $(\mathrm{NR})$ and nitrite reductase (NiR) prior to fixation into amino acids through the glutamine synthetase (GS) pathway. The nitrate reductase activity of Scytonema was reduced by $93 \%$ when treated with $10 \mathrm{ppm}$ Acenapthene concentration and 97\% when treated with Fluoranthene. Prasad et al. 2006 studied the biological effects of a fungicide on Nostoc muscorum and quoted similar results. Glutamine synthetase, an important ammonia-assimilating enzyme, displayed a significant inhibition upon the PAHs treatment, leading to a $94 \%$ (acenapthene) and 95\% (fluoranthene) reduction in enzyme activity when compared with their control. This observation has also been further supported by findings of a remarkable decrease in GS activity resulting from different pesticides Rajendran, 2007. Succinate dehydrogenase activity was severely diminished by $88 \%$ when treated with acenapthene and $93 \%$ when treated with fluoranthene Phillips et al. 1993 and further stated that the inhibition of succinate dehydrogenase in the fungi Rhizoctania solani resulted from treatment with thiazole carboxanilide fungicides (fig 10,11 and 12). The $\mathrm{C} / \mathrm{N}$ ratio increased slightly from $4.2 \pm 0.1$ in the control culture to $5.39 \pm 1.5$ in the concentration of 5 ppm acenapthene treated culture, and then fell somewhat to reach $4.0 \pm 0.1$ in $10 \mathrm{ppm}$ with polluted cells at the end of $16^{\text {th }}$ day. Same as in fluoranthene treated culture; the $\mathrm{C} / \mathrm{N}$ ratio was $4.0 \pm 0.13$ at the end of $16^{\text {th }}$ day. Carman et al. (1997) found that hydrocarbon contamination enhanced nitrogen availability. Other investigators (Burkhardt et al. 1999, Riebesell et al. 2000) demonstrated that the $\mathrm{C} / \mathrm{N}$ ratio was influenced by a carbon enriched culture medium. In contrast, Chabbi \& Rumpel (2004) considered that $\mathrm{C} / \mathrm{N}$ ratios are a consequence of the presence of decomposing plant and/or microbial (including algae) residues. In this connection, our results regarding $\mathrm{C} / \mathrm{N}$ ratios were slightly elevated relative to the control up to $50 \%$ aqueous diesel extract concentration. After that, the ratio decreased again to approximately the control value, a result indicative of the constant proportions of the two elements despite the addition of the pollutant. The elemental abundance in algae is apparently controlled by the elemental abundance in the medium, whereas metabolic processes as well as environmental factors relevant to the habitat modify the final concentration of a given element in the algal cell (S'anchez-Rodr'1guez et al. 2001).Both DNA and RNA of Scytonema sp. were affected by different Acenapthene and Fluoranthene concentrations. Reduction in DNA and RNA was observed in all treated cultures with increasing incubation period. DNA reduced by $93 \%$ in treated with acenapthene and $95 \%$ by fluoranthene at the end of $16^{\text {th }}$ day. likewise, RNA content reduced to $0.68 \mathrm{mg} \mathrm{ml}^{-2}$ of acenapthene and $0.54 \mathrm{mg} \mathrm{ml}^{-20}$ treated with fluoranthene in Scytonema sp. Zachleder V and Tukaj Z (1993) have reported that inhibition of DNA synthesis in response to high concentrations of oil is accompanied by slightly delayed in cessation of RNA and protein synthesis. This explains the probable nucleic acid variation pattern in cyanobacteria (Scytonema sp.). Results demonstrated that DNA and RNA synthesis are inhibited at higher concentration indicating that the biosynthesis of these compounds is probable targets of PAH toxicity. The isolate under study was tested for its ability to grow in the presence of varying concentrations of the PAHs. This study has revealed that PAHs treatment adversely affects the growth of the isolate, even at lower concentrations of 10 and 20 ppm. The release of metabolites such as carbohydrates, proteins, amino acids, and phenols as well as enzymes such as nitrate reductase, glutamine synthetase, and succinate dehydrogenase were all unfavorably affected by increasing concentrations of PAHs treatments.

\section{Acknowledgement}

Authors would like to show their gratitude towards SICART, for providing laboratory as well as instrumentation facility. 


\section{References}

Albers Peter H (1995) Petroleum and Individual Polycyclic Aromatic Hydrocarbons: In Handbook of Ecotoxicology. Lewis Publishers. pp.330.

Ansari ZA, Saldanha MC, Rajkumar R (1997) Effects of petroleum hydrocarbons on the growth of microalgae Isicrysis sp. (Chrysophyta). Indian J. Mar. Sci. 26: 372376.

Arias AH, Spetter CV, Freije RH and Marcovecchio JE (2009) Polycyclic aromatic hydrocarbons in water, mussels (Brachidontes sp., Tagelus sp.) and fish (Odontesthes sp.) from Bahía Blanca Estuary, Argentina. Estuarine. Coastal and Shelf Science 85: 67-81. DOI: 10.1016/j.ecss.2009.06.008

Barrett GC and Elmore DT (1998) Amino acids and peptides, Cambridge Univ. Press, 240 DOI: 10.1017/CBO9781139163828

Bennett A and Bogorad L (1973) Complementary chromatic adaptation in a filamentous bluegreen alga. J. Cell Biol. 58: 419-435. DOI: $10.1083 / \mathrm{jcb} .58 .2 .419$

Botta C, Di Giorgio C, Sabatier AS, De Meo M (2009) Effects of UVA and visible light on the photogenotoxicity of benzoapyrene and pyrene. Environmental Toxicology 24: 492-505. DOI: 10.1002/tox.20455

Brown MR, McCausland MA and Kowalski K (1998) The nutritional value of four Australian microalgal strains fed to Pacific oyster Crassostrea gigas spat. Aquaculture 165 (3): 281-293. DOI: 10.1016/S0044-8486(98)00256-7

Burkhardt S, Zondervan I and Riebesell U (1999) Effects of CO2 concentration on $\mathrm{C}: \mathrm{N}: \mathrm{P}$ ratio in marine phytoplankton: a species comparison, Limnol. Oceanogr., 44 (3): 683-690. DOI: 10.4319/lo.1999.44.3.0683

Carman KR, Fleeger JW and Pomarico SM (1997) Response of benthic food web to hydrocarbon contamination, Limnol. Oceanogr., $42 \quad$ (3): $561-571 . \quad$ DOI: 10.4319/lo.1997.42.3.0561

Cerniglia CE (1992) Biodegradation of polycyclic aromatic hydrocarbons.Biodegradation 3:351-368. DOI: 10.1007/BF00129093

Cerniglia CE, Baalen CV and Gibson DT (1980) Metabolism of naphthalene by the cyanobacterium Oscillatoria sp., strain JCM. J. Gen. Microbiol. 116:485-494.

Chabbi A and Rumpel C (2004) Chemical composition of organic matter in extremely acid, lignite-containing lake sediments impacted by fly ash contamination, J. Environ. Qual. 33 (2): 628-636. DOI: $10.2134 /$ jeq2004.6280

Coates JD,Woodward J,Allen J, Philp P and Lovley DR (1997) Anaerobic Degradation of Polycyclic Aromatic Hydrocarbons and Alkanes in Petroleum Contaminated Marine Harbor Sediments. Applied and Environmental Microbiology 63 (9): 3589-3593.

Dennington VN, George HM and Wybron CHE (1975) The effect of oil on growth of fresh water phytoplankton, Environ. Pollut., 8: 233-237. DOI: 10.1016/0013-9327(75)901056
El-Sheekh MM (2000) Effect of glyphosate herbicide on growth, photosynthesis and some metabolic activities on the green alga Chlorella kessleri (Chlorophyta). Egypt. J. Phycol. 1: 87-97.

England PA, Harford-Cross F, Stevenson J, Rouch D and Wong L (1998) The oxidation of naphthalene and pyrene by cytochrome P450cam. FEBS Letter 424: 271-274. DOI: 10.1016/S0014-5793(98)00189-6

Guerrero MG, Vega JM, and Losada M (1981) The Assimilatory nitrate reducing system and its regulation. Annu. Rev. Plant Physiol. 32: 169-204. DOI: 10.1146/annurev.pp.32.060181.001125

Ikawa M, Mosley SP and Barbero LJ (1992) Inhibitory effects of terpene alcohols and aldehydes on growth of green alga Chlorella pyrenoidosa. J. Chem. Ecol. 18 (10): 17551760. DOI: $10.1007 / \mathrm{BF} 02751100$

Jeffrey SW and Humphrey GF (1975) New spectrophotometric equations for determining chlorophylls $\mathrm{a}, \mathrm{b}, \mathrm{c} 1$ and $\mathrm{c} 2$ in higher plants, algae and natural populations. Biochem. Physio. Pflanzen. 167: 191-194.

Jensen MH, Nielsen TG and Dahllöf I (2008) Effects of pyrene on grazing and reproduction of Calanus finmarchicus and Calanus glacialis from Disko Bay, West Greenland. Aquatic Toxicology 87:99-107. DOI: 10.1016/j.aquatox.2008.01.005

Kanika S, Lakshmi N, Venugopalan K, Mehta P, Maheshwar A, and Baph S (2003) X-ray diffraction: An approach to study interaction between cyanobacteria and dairy effluent. Curr. Sci. 85:1330-1334.

Kapoor K, Leenta and Arora (1996) Observations on growth Responses of cyanobacteria under the influence of herbicides. Pollut. Res. 15: 343-351.

Koksharova OA and Wolk CP (2002) Genetic tools for cyanobacteria. Appl. Microbiol. Biotechnol. 58: 123-137. DOI: $10.1007 / \mathrm{s} 00253-001-0864-9$

Kun E, and Abood LG (1949) Colorimetric estimation of succinic dehydrogenase by triphenyl tetrazolium chloride. Sci. 109(2824): 144-146. DOI: 10.1126/science.109.2824.144

Lai B and Khanna S (1996) Mineralization of 14C octacosane by Acinetobacter calcoaceticus S30. Can. J. Microbiol. 42: 1225-1231. DOI: $10.1139 / \mathrm{m} 96-158$

Lee Y and Takahanshin T (1966) An imported colorimetric determination of amino acids with the use of ninhydrin. Anal Biochem. 14:71-77. DOI: 10.1016/00032697(66)90057-1

Lowry OH, Rosenbrough NH, Farr AL and Randall RJ (1951) Protein measurements with folinphenol reagent. J. Biol. Chem. 193:265-275.

Malick CP and Singh MB (1980) Plant Enzymology and Histo Enzymology. Kalyani Publishers, New Delhi, pp. 286.

Mallick N and Rai LC (1994) Kinetic Studies of Mineral Uptake and Enzyme Activities of Anabaena doliolum under metal stress. J. Gen. Appl. Microbiol. 40: 122-133. 
Mastral AM, Callén MS (2000) A review on polycyclic aromatic hydrocarbon (PAH) emissions from energy generation. Environmental Science \& Technology 34:3051-3057. DOI: $10.1021 / \mathrm{es} 001028 \mathrm{~d}$

Nagwa Gamal-El-Din Mohammady,Yean-Chang Chen,Abd-ElRuhman Aly El-Mahdy, Rania Farag Mohammad (2005) Physiological responses of the eustigmatophycean Nannochloropsis salina to aqueous diesel fuel pollution. Oceanologia 47 (1): 75-92.

Office of the Federal Registration (OFR) (1982) Appendix A: priority pollutants. Federal Register, 52309.

Oliveira M, Pacheco M and Santos MA (2007) Cytochrome $\mathrm{P} 4501 \mathrm{~A}$, genotoxic and stress responses in golden grey mullet (Liza aurata) following short-term exposure to phenanthrene. Chemosphere 66:1284-1291. DOI: 10.1016/j.chemosphere.2006.07.024

OSPAR-Commission (2000) Quality Status Report. OSPAR Commission, London, United Kingdom. PAH mineralization and Biodegradation Intermediates. Manual of Environmental Microbiology 766-775.

Pamiljans V, Krishnaswamy PR, Dumville G, and Meister A (1962) Studies on the mechanism of glutamine synthetase: isolation and properties of the enzyme from sheep brain. Biochem. 1:153-158. DOI: 10.1021/bi00907a023

Phillips GW and Rejda JM (1993) Thiazole carboxanilide Fungicides: A new structure - activity relationship for succinate Dehydrogenase inhibitors. Pestic. Sci. 38: 1-7. DOI: $10.1002 / p s .2780380102$

Plummer DT (1998) An introduction to practical biochemistry, Third edition, (Tata McGraw-Hill Publication, New Delhi), pp. 220-221.

Prasad AB, Samanta R, Vishwakarma ML, and Vaishampayan A (2006) Biological effects of a mercury fungicide On a $\mathrm{N}_{2-}$ fixing blue-green alga Muscorum: Isolation and Preliminary Characterization of an Hg-resistant Mutant. New Phytol. 102:45-49. DOI: 10.1111/j.14698137.1986.tb00796.x

Rajendran UM, Kathirvel E and Narayanaswamy A (2007) Effects of a fungicide, an insecticide, and a biopesticide on Tolypothrix scytonemoide. Pestic. Biochem. Physiol. 87:164-171. DOI: 10.1016/j.pestbp.2006.07.006

Riebesell U, Revill AT, Holdsworth DG and Volkman JK (2000) The effect of varying $\mathrm{CO}_{2}$ concentration on lipid composition and carbon isotope fractionation in Emiliania huxleyi. Geochim. Cosmochim. Acta, 64 (24): 4179-4192. DOI: 10.1016/S0016-7037(00)00474-9

Roe JH (1955). The determination of sugar in blood and spinal fluid with anthron reagent. J. Biol. Chem. 2112: 335-343.

S'anchez-Rodr'iguez I, Huerta-Diaz MA., Choumiline E, Holgu'ın-Qui nones O and Zertuche-Gonz'alez JA (2001) Elemental concentrations in different species of seaweeds from Loreto Bay, Baja California Sur, Mexico: implications for the geochemical control of metals in algal tissue, Environ. Pollut. 114 (2):145-160.

Sempruch C, Ciepiela AP, Sprawka I and Chrzanowski G (2008) Purification and some physicochemical properties of nitrate reductase isolated from winter triticale seedlings. Electronic journal of polish agricultural universities, 11(1).

Shuttleworth K, and Cerniglia C (1996) Practical Methods for the isolation of Polycyclic aromatic hydrocarbon (PAH)Degrading Microrganisms and the determination of PAH mineralization and Biodegradation Intermediates. Manual of Environmental Microbiology 766-775.

Tongpim S, Pickard MA (1996) Growth of Rhodococcus S1 on anthracene, Can. J. Microbiol. 42 (3): 289-294. DOI: $10.1139 / \mathrm{m} 96-042$

Vives I, Grimalt JO, Fernandez P, Rosseland B (2004) Polycyclic aromatic hydrocarbons in fish from remote and high mountain lakes in Europe and Greenland. Science of the Total Environment 324:67-77. DOI: 10.1016/j.scitotenv.2003.10.026

Warshawsky D, Cody T, Radike M, Reilman R, Schumann B, LaDow K and Schneider J (1995) Biotransformation of benzo[a]pyrene and other polycyclic aromatic hydrocarbons and heterocyclic analogs by several green algae and other algal species under gold and white light.

Yehuda Cohen (2002) Bioremediation of oil by marine microbial mats. Int. Microbiol. 5: 189-193. DOI: 10.1007/s10123002-0089-5

Zachleder V and Tukaj Z (1993) Effect of fuel oil and dispersant on cell cycle and macromolecule synthesis in the chlorococcal alga Scendesmus armatus, Mar. Biol. 117:347-354. DOI: 10.1007/BF00345680 